the more sophisticated college students and the agriculture students in the matter of rigoristic and latitudinarian answers? The agriculture students are far more rigoristic. Professor Sharp believes that the explanation for this is to be found not in the influence of custom or the authority of the Bible, but " partly in the difference in education and average culture in the two classes, partly in the particular circumstances of their lives." Is not the 'difference in education' another way of spelling increased attention to the values of life on the one hand and to rational methods of procedure on the other? But both of these aspects of education would tend to replace custom. And as to the 'particular circumstances' I should incline to think that the social groups to which those questioned had belonged were more important than the physical conditions.

In conclusion, then, we should all agree that our explicit moral judgments tend to be reasoned. The present writer, however, believes that a large stratum of conduct is customary, in the sense that our approval is largely dependent on the current attitudes of our group. Who shall say that modes of women's dress, of dancing, of business or professional conduct, are approved or disapproved on purely reasoned bases, or that in our notion of what is decent or indecent, proper or improper (and these shade imperceptibly into right and wrong for the judgment of common sense) we can detach ourselves wholly from the group or class and form 'individual' valuations or judgments?

\title{
LOYALTY.
}

$$
\text { J. H. T. }
$$

The Philosophy of Loyalty. JosiaH Royce. New York, The Macmillan Co., 1908. Pp. xiii + 409. Price \$r.50.

Sub specie fidelitatis! To reduce the virtues to one has proved to many a fascinating task. Wisdom, pleasure, perfection, duty, love, benevolence, rationality, power, and other concepts have served in turn as such an ultimate. Each has a fair claim to stand for some valuable aspect of the moral life. But none has established itself as adequate to satisfy the complex demands of reflection and action, of reason and feeling, of order and progress, of individual development and social claim. The point of view from which Professor Royce paints his picture is one that enables him to bring out certain values strongly. And it scarcely needs to be said that the coloring, the light and shade, the detail that helps the central motive, are all handled with masterly skill. Professor Royce knows how to present his mes-. sage to the wide public that is ready to welcome philosophy provided 
it is not required to learn a new language at the same time. But as the picture claims not only to be $a$ picture, but a picture from a point of view which is adequate for comprehending the whole duty of man it must be so considered.

Loyalty as a central principle has this in its favor at the outset: it derives from one of the fundamental elements in early morality. In its simpler forms loyalty to clan, or chief, to tribal brother or ancestral god, exhibits the capacity to pass beyond the bounds of a physical self and recognize a social bond and social claim. Loyalty to a cause, which is the type of loyalty that the author holds up as the fulfilling of the law, is a more impersonal phase of the same attitude. In thus depersonalizing the conception of loyalty the question is, What content do we substitute for the old? For, whereas there was but one chief or clan there are many 'causes.' To which shall I be loyal? Doubtless I cannot serve God and mammon; but are not mammon's servants as loyal as God's? The formula that is presented as a criterion for our choice here sounds at first as purely formal as, Do your duty. It is, 'Be loyal to loyalty.' This, however, is not ultimate. On the one hand it is traced back to a more specifically individual act; on the other, the conception of loyalty is given a new social content.

The individualistic answer to the question, which cause? is: "Decide as I, your conscience, the ideal expression of your whole personal nature, find best." "We are fallible but we can be decisive and faithful." It may go without challenge that decision is necessary for moral conduct, and that it is noble to be faithful to a well chosen cause. But on this subjective side of conduct is there no further word? Certainly we cannot demand of a principle that it shall make our choices, but should it not give instruction as to the method of making them? Professor Royce refers us to the self as unified by a purpose, the purpose of loyalty. "It is devoting the self to a cause that after all first makes it a rational and unified self," and conscience is the voice of such a self. But adınitting the value of all this, is it not important to stress also the aspect of reflection, and especially of investigation by scientific methods, if man is to find his cause? For one I believe that the most hopeful sign of present day morality as we see it actually at work is this use of scientific method in place of the chaos, the subjectivism, or the fanaticism of the older morality. Faithfulness is one side, but actual moral progress demands that we do not lavish our service in pathetic devotion to the wrong cause.

We turn then to the social content that is given to the principle. Loyalty to loyalty means 'an unity with the unity of all buman life" 
(p. 126). "A cause means something that is conceived by its loyal servant as unifying the lives of various human beings into one life" (p. 252). Loyalty means unity. And there can be no question that unity is a true social note. None the less when we ask whether this is the note most needed, we must settle with an ambiguity.

A unity is at least theoretically conceivable along the lines of subordination worked out by Plato and cherished by many as the only possible type. But another more democratic conception is hovering in the horizon of some. It involves a remaking of human nature, it is true, but just this constitutes its lure. I do not mean to suggest that Professor Royce's conception of unity will not welcome this as a possible mode, but it can scarcely be said to demand it. And I doubt whether any formulation which does not make this a dominant note will strike the deepest chords of the European and American conscience of to-day. It is because of this prior demand that ' justice' is likely for some time to come to evoke a larger response than unity. We must have unity. Yes, but we will struggle for justice first. For no unity is permanent, and none is fully moral that does not include justice.

In his later chapters on 'Loyalty, Truth and Reality' and ' Loyalty and Religion' the author devotes himself to the correction of the pragmatists, and with a neat turn borrows a phrase in which to frame his final definition of loyalty: Loyalty is the Will to Believe in something eternal, and to express that belief in the practical life of a human being.

J. H. T.

\section{PSYCHOLOGY OF ADVERTISING.}

The Psychology of Advertising. Walter DrLL Scott. Boston, 1908. Pp. 269.

While every one has been vaguely aware that there is a great deal of 'psychology' involved in advertising, Professor Scott deserves the credit of being the first to work out clearly and definitely the application of psychological principles to this field of activity. This work treats specifically of memory, the feelings and emotions, sympathy, instinct, suggestion, the will, habit, and attention, showing with what principles in each of these processes the advertiser has to reckon, and in what way. His points are illustrated by familiar advertisements taken chiefly from the magazines. He also gives the results of investigations which throw light upon the amount of time that the average reader of a magazine devotes to looking over its advertisements, the 